\section{Archives of}

Agriculture

\section{Research and}

\section{Technology (AART)}

Volume 1 Issue 4, 2020

Article Information

Received date : November 29, 2020

Published date: December 28, 2020

\section{*Corresponding author}

David L Jordan, Department of Crop and Soil Sciences, North Carolina State University, USA

\section{Keywords}

Calcium nutrition; Soil fertility; Lime

Distributed under Creative Commons CC-BY 4.0

\section{Peanut Response to Interactions of Soil pH and Gypsuim}

\author{
David L Jordan ${ }^{1^{*}}$ and J Steven Barnes ${ }^{2}$ \\ ${ }^{1}$ Department of Crop and Soil Sciences, North Carolina State University, USA \\ ${ }^{2}$ North Carolina Department of Agriculture and Consumer Services, Peanut Belt Research Station, USA
}

\section{Abstract}

Soil $\mathrm{pH}$ and supplemental calcium applied as gypsum can affect peanut yield. The interaction of soil $\mathrm{pH}$ and gypsum applied at flowering is not clearly defined in the peer-reviewed literature. Research was conducted in North Carolina in the USA to determine peanut yield when grown in soil with $\mathrm{pH}$ values of 4.5, 5.2, 5.6, and 6.0 when no gypsum or gypsum at 340 and $680 \mathrm{~kg} / \mathrm{ha}$ was applied at the flowering stage of peanut. Peanut yield increased as soil pH increased in absence of gypsum. Applying gypsum at both rates increased peanut yield when soil pH was 4.5 or 6.0 compared with the no-gypsum control. However, at a soil pH of 5.2 gypsum did not increase yield. At a soil pH of 5.6 gypsum did not affect yield when applied at 340 $\mathrm{kg} / \mathrm{ha}$; gypsum at $680 \mathrm{~kg} / \mathrm{ha}$ decreased yield. Results from these experiments demonstrate that peanut response to gypsum can be dependent on soil $\mathrm{pH}$ and that soil $\mathrm{pH}$ should be considered when deciding when to apply gypsum to supplement native calcium in soil.

\section{Introduction}

Virginia market type peanut (Arachis hypogaea L.) often require supplemental calcium applied at flowering to optimize pod yield and market grade factors [1-4]. Peanut yield is also optimized when soil pH is between 5.8 and 6.2 [2,4]. Both lime to neutralize soil $\mathrm{pH}$ and gypsum to supplement native calcium in soil can be expensive. For example, in NC State Extension enterprise budgets for peanut the cost of lime for a single season when prorated over 3 years is set at approximately $\$ 42 / \mathrm{ha}[5]$. The potential financial return on investment from lime in North Carolina for peanut production during 2018 was estimated at 11:1 based on assumptions associated with planted area, percentage of growers with soil pH between 5.5 and 5.6, and average peanut yield for the state [6]. The cost of gypsum using the same enterprise budgets in North Carolina is $\$ 70 /$ ha [5]. Although variation in peanut response to gypsum can occur $[1,3]$, the general recommendation is that Virginia market type cultivars require supplemental calcium [1].

The interaction of soil $\mathrm{pH}$ and gypsum has not been clearly defined in the peer-reviewed literature. Research in North Carolina [3] indicated that a rate of gypsum that was 50\% higher than the suggested use rate reduced peanut yield when soil pH was lower than recommended in some experiments. Based on soil testing data provided by the North Carolina Department of Agriculture and Consumer Sciences, approximately $25 \%$ of soil samples from farmers for peanut production had soil pH levels below the recommended range for peanut [6]. Additionally, peanut is produced in many areas of the world in soils with low $\mathrm{pH}$ [7-9]. However, as inputs including lime and fertilizer become more available and credit to purchase these inputs increases, information on possible interactions of lime and gypsum is needed. In circumstance where land tenure issues exist or access to inputs or credit for purchase (e.g. lime to neutralize soil $\mathrm{pH}$ ), farmers may focus on inputs that can be used in a single year for peanut (e.g. gypsum) rather lime. Neutralizing soil pH could benefit subsequent crops while gypsum benefits only peanut in that growing cycle. To provide information for these decisions in the peer-reviewed literature, results from research conducted in North Carolina defining interactions of soil $\mathrm{pH}$ and gypsum are provided in this article.

\section{Materials and Methods}

The experiment was conducted in 2001, 2002, and 2003 near Lewiston-Woodville, NC in the USA (36.135 N, -77.177 $\mathrm{W}$ ) in a field with $\mathrm{pH}$ regimes of approximately 4.5, 5.2, 5.6, and 6.0. Soil was a Norfolk loamy sand soil (fine-loamy, siliceous, thermic Typic Paleudult) with $80 \%$ sand, $12 \%$ silt, and $8 \%$ clay, a cation exchange capacity of 3.8 to 6.0 , and $1.2 \%$ organic matter content. These $\mathrm{pH}$ regimes were established for other experiments in previous years. A gypsum source containing $85 \% \mathrm{CaSO}_{4}$ (USG Ben Franklin Agricultural Gypsum, Chicago, IL USA) was applied in a $48 \mathrm{~cm}$ band over each row at rates of 0,340, and 680 $\mathrm{kg} / \mathrm{ha}$ for each soil $\mathrm{pH}$ regime at the R1 stage of peanut development [10] of the cultivar NC 7 [11]. The experimental area was conventionally tilled prior to planting peanut on raised seedbeds spaced $96-\mathrm{cm}$ apart to achieve a final in-row plant population of 15 plants $/ \mathrm{m}$. Peanut pods were dug and vines inverted based on pod mesocarp color to optimize yield. Final yield was adjusted to $8 \%$ moisture.

The experimental design was randomized complete block with 4 replications. Percent of maximum yield was calculated using the highest yielding plot for each replication and year combination. Data for percent of maximum yield were subjected to analysis of variance for a soil $\mathrm{pH}$ regime $\times$ gypsum rate factorial arrangement of treatments pooled over years. Means were separated using Fisher's Protected LSD test at $\mathrm{p}<0.10$

Results

When pooled over years, significant main effects of both soil pH regime $(\mathrm{p}<0.0001, \mathrm{~F}$ ratio $=66.5)$, gypsum rate $(\mathrm{p}=$ $0.0498, \mathrm{~F}$ ratio $=3.1)$, and the interaction of soil $\mathrm{pH}$ regime and gypsum rate $(\mathrm{p}=0.0939, \mathrm{~F}$ ratio $=1.9)$ were observed (coefficient of variation $=20.8$ ). When pooled over years and gypsum rates, percent of maximum yield at $\mathrm{pH} 4.5(51 \%)$ and $\mathrm{pH} 5.2(57 \%)$ was similar and lower than yield for $\mathrm{pH} 5.6$ and pH 6.0 (data not shown in tables). Yield of peanut grown in soil with $\mathrm{pH} 6.0(84 \%)$ exceed yield for $\mathrm{pH} 5.6(75 \%)$ (data not shown in tables). When pooled over soil $\mathrm{pH}$ regimes, applying gypsum at $340 \mathrm{~kg} / \mathrm{ha}$ or 
$680 \mathrm{~kg} / \mathrm{ha}$ increased yield from $65 \%$ to $70 \%$ and $72 \%$, respectively.

A major objective of this research was to determine if peanut response to gypsum varied based on soil $\mathrm{pH}$. When pooled over years, percent of maximum yield ranged from $42 \%$ to $55 \%$ across gypsum rates at $\mathrm{pH} 4.5$ with gypsum at 340 and $680 \mathrm{~kg} / \mathrm{ha}$ resulting in greater yields compared with the no-gypsum control (Table 1). Percent of maximum yield ranged from $55 \%$ to $59 \%$ at $\mathrm{pH} 5.2$ and did not differ regardless of gypsum rate. At $\mathrm{pH} 5.6$, applying gypsum at $680 \mathrm{~kg} / \mathrm{ha}$ resulted in lower yields compared to the nogypsum control and gypsum at $340 \mathrm{~kg} / \mathrm{ha}$. When gypsum was applied at $340 \mathrm{~kg} / \mathrm{ha}$ and $680 \mathrm{~kg} / \mathrm{ha}$ peanut yield was greater at $\mathrm{pH} 6.0$ compared with yield without gypsum; yield was similar for gypsum rates of and 340 and $680 \mathrm{~kg} / \mathrm{ha}$. These data indicate that at very low $\mathrm{pH}(\mathrm{pH} 4.5)$ and $\mathrm{pH}$ in the suggested range for peanut ( $\mathrm{pH} 6.0$ ) a positive response to gypsum was observed. No differences in response to gypsum were observed at $\mathrm{pH}$ 5.2. The lower yield when gypsum was applied at $680 \mathrm{~kg} / \mathrm{ha}$ when soil $\mathrm{pH}$ was 5.6 compared with gypsum at $340 \mathrm{~kg} / \mathrm{ha}$ or the no gypsum control needs to be investigated further. Jordan et al. [3] reported that rates above the recommended use rate applied to peanut when soil $\mathrm{pH}$ was 5.6 resulted in a decrease in yield compared with the no gypsum control or gypsum applied at the recommended use rate. In the same study, when soil $\mathrm{pH}$ was closer to the recommended use value the higher rate of gypsum did not negatively affect peanut yield regardless of gypsum rate.

Table 1: Peanut response to soil $\mathrm{pH}$ and gypsum rate.

\begin{tabular}{|c|c|c|c|}
\hline \multicolumn{4}{|c|}{ Peanut yield } \\
\hline \multirow{3}{*}{ Approximate soil pH } & 0 & 340 & 680 \\
\cline { 2 - 4 } & \multicolumn{3}{|c|}{ Percent of maximum yield } \\
\hline 4.5 & $42 \mathrm{f}(4.2) \mathrm{b}$ & $55 \mathrm{e}(4.3)$ & $55 \mathrm{e}(4.1)$ \\
\hline 5.2 & $55 \mathrm{e}(4.7)$ & $56 \mathrm{e}(4.7)$ & $59 \mathrm{e} \mathrm{(6.3)}$ \\
\hline 5.6 & $78 \mathrm{c}(4.8)$ & $78 \mathrm{c}(4.8)$ & $69 \mathrm{~d}(6.2)$ \\
\hline 6 & $84 \mathrm{~b}(3.9)$ & $97 \mathrm{a}(2.4)$ & $95 \mathrm{a}(2.2)$ \\
\hline
\end{tabular}

${ }^{a}$ Means followed by the same letter are not significantly different based on Fisher's Protected LSD test at $\alpha=0.05$. Data are pooled over 3 years. ${ }^{b}$ Standard error in parenthesis.

\section{Discussion}

Results from this research provide information that can be used to help farmers and those making recommendations to farmers decide if gypsum is warranted based on soil $\mathrm{pH}$. While these results were derived from one location over 3 years, they demonstrate that interactions of soil $\mathrm{pH}$ and gypsum rate can occur. In circumstances where resources are limited and soil $\mathrm{pH}$ is relatively low, farmers may decide the benefit of applying gypsum is not warranted. It is important to note that there can be confusion on defining gypsum and lime rates based on the method of application. For example, a rate may be described per ha but the product is applied in a concentrated manner closer to the plant. Based on our results, the possibility of interactions among soil $\mathrm{pH}$ and gypsum rate can occur, and specific rates need to be developed and evaluated under local conditions where soil characteristics are known.

Peanut response to $\mathrm{pH}$ is well established and has been documented across cultivars and botanical classifications $[1,3,4]$. Response to gypsum can be associated with seed size but also can be impacted by soil chemical characteristics, native levels of soil calcium in soil, balance of nutrients in soil, application rate of gypsum, and rainfall [1-4, 7-9].

\section{Acknowledgement}

This publication was made possible in part through support provided by the Office of Agriculture, Research and Policy, Bureau of Food Security, U.S. Agency for International Development, under the terms of Award No. AID-ECG-A-00-07-0001 to The University of Georgia as management entity for U.S. Feed the Future Innovation Lab on Peanut Productivity and Mycotoxin Control (2012-2017). The opinions expressed herein are those of the authors and do not necessarily reflect the views of the U.S. Agency for International Development. The North Carolina Peanut Growers Association, Inc. provided partial funding for this research. Appreciation is expressed to technical staff at the Peanut Belt Research Station for assistance with this research.

\section{References}

1. Gaines TP, Parker MB, Walker ME (1989) Runner and Virginia type peanut response to gypsum in relation to soil calcium level. Peanut Science 16(2): 116-118.

2. Jordan DL (2021) Peanut production practices in 2021 Peanut Information. NC State Extension Publication AG-331, pp. 21-46.

3. Jordan DL, Johnson PD, Spears JF, Penny B, Hardy D (2010) Response of Virginia market type peanut to interactions of cultivar, calcium, and potassium. J Crop Management 9(1):1-10.

4. Sullivan GA, Jones GL, Moore RP (1974) Effects of dolomitic limestone, gypsum, and potassium on yield and seed quality of peanuts. Peanut Science 1(2): 73-77.

5. Washburn D, Jordan DL (2021) Peanut production budgets. Peanut Information. NC State Extension Publication AG-331, pp. 2-15.

6. Jordan D, Hardy D, Barnes S, Corbett T (2020) Potential economic value for peanut by increasing soil $\mathrm{pH}$ in North Carolina. J Crop, Forage, and Turfgrass Management 6(1).

7. Syed OSR, Shamsuddin ZH, Zuraidah JY, Wynne JC, Elkan GH (1991) Use of lime, gypsum and their combinations to improve nodulation and yield of groundnut in an acidic soil. In: Wright RJ, Baligar VC, Murrmann RP, eds. Plant-Soil Interactions at Low pH: Developments in Plant and Soil Sciences. 45. Springer, Dordrecht.

8. Thilakarathna, SMCR, Kirthisinghe JP, Gunathilaka BL, Dissanayaka DMPV (2014) Influence of gypsum application on yield and visual quality of groundnut (Arachis hypogaea L.) grown in Maspotha in Kurunegala District of Sri Lanka. Tropical Agricultural Research 25(3): 432-436.

9. Ullah MA, Hyder SI, Ahmed R (2019) Effect of gypsum application on groundnut growth and nodules under rain fed condition. International Journal of Research in Agriculture and Forestry 6(10): 8-13.

10. Boote K (1982) Growth stages of peanut (Arachis hypogaea L.). Peanut Science 9(1): 35-40.

11. Wynne JC, Mozingo RW, Emery DA (1979) Registration of NC 7 peanut (Reg. No. 22). Crop Science. 19(4): 563. 